University of Nebraska - Lincoln

DigitalCommons@University of Nebraska - Lincoln

Faculty Publications: Department of Entomology

Entomology, Department of

April 1999

CHRONIC EFFECTS OF ATRAZINE ON TOLERANCE OF A BENTHIC DIATOM

Karen J. Nelson

University of Nebraska-Lincoln

Kyle D. Hoagland

University of Nebraska-Lincoln, khoagland1@unl.edu

Blair Siegfried

University of Nebraska-Lincoln, bsiegfried1@ufl.edu

Follow this and additional works at: https://digitalcommons.unl.edu/entomologyfacpub

Part of the Entomology Commons

Nelson, Karen J.; Hoagland, Kyle D.; and Siegfried, Blair, "CHRONIC EFFECTS OF ATRAZINE ON

TOLERANCE OF A BENTHIC DIATOM" (1999). Faculty Publications: Department of Entomology. 54.

https://digitalcommons.unl.edu/entomologyfacpub/54

This Article is brought to you for free and open access by the Entomology, Department of at DigitalCommons@University of Nebraska - Lincoln. It has been accepted for inclusion in Faculty Publications: Department of Entomology by an authorized administrator of DigitalCommons@University of Nebraska - Lincoln. 


\title{
CHRONIC EFFECTS OF ATRAZINE ON TOLERANCE OF A BENTHIC DIATOM
}

\author{
Karen J. Nelson, $\uparrow \S$ Kyle D. Hoagland, $* \dagger$ and Blair D. Siegfried $\$$ \\ $\dagger$ School of Natural Resource Sciences and $\ddagger$ Department of Entomology, University of Nebraska, Lincoln, Nebraska 68583, USA \\ $\S U . S$. Fish and Wildlife Service, 203 West Second Street, Grand Island, Nebraska 68801
}

(Received 27 February 1998; Accepted 19 August 1998)

\begin{abstract}
The effects of prior chronic exposure to atrazine on responses to subsequent acute exposures were investigated using a common benthic diatom. Clonal, axenic cultures of Craticula cuspidata were established from the Platte River (Nebraska) and obtained from a culture collection (unlikely prior exposure to atrazine). All cultures received a chronic $67-\mathrm{d}$ treatment of $1 \mu \mathrm{g} / \mathrm{L}$ atrazine, and growth was monitored using fluorometric detection of chlorophyll $a$. Chronic atrazine exposure significantly reduced growth rate only during the first day of treatment $(p=0.0001)$; no significant effect was detected throughout the remainder of the 67-d period. Following the chronic treatment, clones were exposed to six atrazine concentrations $(83,188,402,860,1,782$, and $3,250 \mu \mathrm{g} / \mathrm{L}$ ) to ascertain whether prior exposure influenced the tolerance of this diatom. Prior chronic exposure had a negative effect on growth following subsequent exposures to higher concentrations. A significant decline in growth was detected on days 7,9 , and 12 between previously exposed and control clones at $83 \mu \mathrm{g} / \mathrm{L}$ of atrazine. The lack of increased tolerance in C. cuspidata after a realistic chronic exposure indicates that the levels of atrazine presently found in many lotic systems may inhibit the growth of periphyton during periods of higher pulses of atrazine characteristic of spring runoff events.
\end{abstract}

Keywords-Atrazine Periphyton Chronic exposure Tolerance

\section{INTRODUCTION}

Aquatic ecosystems are integrally connected to adjacent landscapes and subject to agricultural activities and the accompanying negative impacts on water quality. Over half of all river kilometers in the United States are moderately to severely impacted by agriculture [1]. Although most of this degradation is due to sediment and nutrients in surface runoff, pesticide presence in rivers is becoming ubiquitous. Thurman et al. [2] detected atrazine in $98 \%$ of 149 midwestern rivers sampled across a 12-state region. Atrazine, an herbicide used to control broadleaf weeds in corn and sorghum, inhibits photosynthesis by disrupting electron transport between the two photosystems [3]. It is the most commonly used herbicide in the United States, with 50 million kilograms applied annually [4]. Atrazine application rates are highest in the midwestern Corn Belt, where many areas have greater than $60 \%$ of their land area planted to corn [5]. An estimated 0.1 to $3 \%$ of applied atrazine enters aquatic systems via surface runoff [6].

Atrazine levels in lotic systems reach a maximum when spring rains result in high volumes of surface runoff. These levels then decline throughout the growing season as atrazine degrades [7], is taken up by plants [8], or moves deeper into the soil matrix [8] and is less likely to enter surface runoff. Atrazine concentrations as high as $691 \mu \mathrm{g} / \mathrm{L}$ have been reported in streams receiving storm runoff from agricultural fields [9]. The U.S. Geological Survey has found atrazine in the Platte River near Grand Island, Nebraska, year-round (U.S. Geological Survey, unpublished data). The high detection frequency of atrazine in many lotic environments raises concern for nontarget primary producers. In many streams, periphyton (attached algae) form the base of the food chain, and thus

* To whom correspondence may be addressed (khoagland@unl.edu). changes in their community composition or abundance have the potential to disrupt higher trophic levels [10].

Many studies have examined the effects of atrazine on algae, revealing a wide sensitivity range among species [11] and even among strains of the same species [12]. Atrazine levels as low as $1 \mu \mathrm{g} / \mathrm{L}$ can cause inhibition in some algae $[13,14]$; however, negative effects are usually not observed unless exposures to higher levels of atrazine are used, especially in field or mesocosm studies [15]. Virtually all investigations on the effects of atrazine on algae in laboratory settings have utilized exposure durations of a few hours to a few days, with longer exposures of atrazine limited to microcosms, enclosures, or experimental ponds [16]. Community-level studies investigating long-term atrazine effects have found differential species responses resulting in changes in community structure at high levels of atrazine (500 $\mu \mathrm{g} / \mathrm{L})$ [17] and no change in community structure at lower concentrations $(5 \mu \mathrm{g} / \mathrm{L})$ [18]. Variations in community response perhaps illustrate some level of tolerance, but species-specific responses are difficult to delineate because of the high levels of variation inherent in community-level or higher bioassays. Although the need for community-level studies for risk assessment is well documented $[19,20]$, single-species assays are still crucial for understanding the effects of chemicals on survival, reproduction, physiology, and biochemistry [19] as well as for delineating the mechanisms responsible for processes such as tolerance or resistance.

Studies have examined algal communities pre-exposed to contaminants to determine whether tolerance changes with subsequent exposure. Periphyton communities exposed to arsenate, for example, were less affected by subsequent exposure [21], and communities exposed to zinc changed less under subsequent $\mathrm{pH}$ changes [22]. Studies investigating prior exposure to atrazine have been unable to establish more tolerant algal communities or clones. Millie and Hersh [12] determined EC50 values for clones of Cyclotella meneghiniana (Bacil- 
lariophyta) using one clone with prior atrazine exposure. The previously exposed clone did not exhibit the highest EC50 reported. Kosinski and Merkle [23] were unable to detect enhanced tolerance in communities pre-exposed to $10 \mu \mathrm{g} / \mathrm{L}$ of atrazine; similar results were obtained by Gustavson and Wängberg [24] and Brockway et al. [25].

The first objective of this study was to determine whether the growth rates of a common benthic diatom from the Platte River were affected by chronic exposure to low (base flow) concentrations of atrazine over several generations and how those rates compared with clones of the same species with no prior exposure to the herbicide. The concentration used for chronic exposure was similar to levels found during much of the growing season in the Platte River. Thus, the alga was exposed to atrazine at a much lower concentration and over a much longer time period (weeks vs days or hours) than in most previous studies. Given the importance of potential herbicide tolerance at the species level to stream ecosystem response to atrazine, a second objective was to determine whether preexposure to low levels of atrazine influenced tolerance to higher concentrations of the herbicide characteristic of spring pulses.

\section{MATERIALS AND METHODS}

\section{Culture establishment and maintenance}

Periphyton samples were collected from five sites along the Platte River, each about $5 \mathrm{~km}$ apart, near Grand Island, Nebraska $\left(40^{\circ} 52^{\prime} 28^{\prime \prime} \mathrm{N}, 98^{\circ} 16^{\prime} 54^{\prime \prime} \mathrm{W}\right)$. Samples were collected in June and July 1994 by removing periphyton from shallow water near sand bars. The diatom Craticula cuspidata (Kütz.) D.G. Mann was selected for study because it was common at all sites. Clonal cultures were established from each site by isolating a single cell in standard soil-water medium. Four clones of the same species were also obtained from the Loras College Freshwater Diatom Culture Collection (Dubuque, IA, USA). Culture collection isolates were originally obtained from Lake Itasca (clones L118, L329, and L1073) and Heart Lake (clone L283), (Minnesota) and they were believed to have had no previous exposure to atrazine. Clonal isolates were treated with an antibiotic mixture [26] diluted 1:10,000 in WC medium [27] for $48 \mathrm{~h}$ to obtain axenic cultures. Luria-Bertani (LB) agar plates [28] were used to confirm whether cultures were axenic. Axenic cultures were used in all treatments to eliminate bacterial degradation of atrazine [7].

Cultures were maintained in $25 \times 150$-mm culture tubes in WC medium with added iron and silica, renewed biweekly, and transferred every 2 weeks to maintain relatively constant atrazine concentrations. Cultures were housed in growth chambers at $20^{\circ} \mathrm{C}$ on a $12: 12 \mathrm{~h}$ light:dark cycle, using cool white fluorescent light at $225 \mu \mathrm{mol} / \mathrm{m}^{2} / \mathrm{s}$.

\section{Pesticide exposures}

Atrazine, 2-chloro-4-ethylamino-6-isopropyl-amino-1,3,5,triazine (98\% purity), was obtained from Chem Service (West Chester, PA, USA). Stock solutions ( $1 \mathrm{mg} / \mathrm{ml})$ were prepared by dissolving atrazine in $100 \%$ ethanol and filter sterilized using a Millex-GS 0.22- $\mu \mathrm{m}$ filter unit (Milli-Q, Bedford, MA, USA). Atrazine stock was added to autoclaved growth medium to achieve desired concentrations, and ethanol was added to the control medium at the same volume.

A chronic $67-\mathrm{d}$ exposure to $1 \mu \mathrm{g} / \mathrm{L}$ of atrazine was chosen on the basis of average levels recorded in the Platte River at base flow (U.S. Geological Survey, unpublished data). Growth medium with atrazine was dispensed into autoclaved culture tubes using sterile technique. Aliquots of each clone were then added to 10 tubes (five containing atrazine) to produce five subreplicates of each clone for each treatment level. This technique was applied to all nine clones, resulting in 90 total tubes. In vivo chlorophyll $a$ fluorescence of all cultures was monitored with a fluorometer (Turner Designs, Sunnyvale, CA, USA, model 10-AU) using a 436-nm excitation filter and a 680-nm emission filter. At the same time of day [29], culture tubes were vortexed and placed in the fluorometer; fluorescence was recorded nine times during each 2 -week period (days $0,1,2,3,4,7,9,11$, and 14). Fluorescence was used as a nondestructive measure of chlorophyll $a$, and growth rate in cell doublings per day (dpd) was calculated with these readings using $\ln F t_{2}-\ln F t_{1} /\left(t_{2}-t_{1}\right) \ln 2$, where $F t_{2}=$ fluorescence at time 2 and $F t_{1}=$ fluorescence at time 1 [30]. At the end of the first 2 weeks, fluorescence was again recorded for each tube, and small aliquots were transferred into fresh medium (with or without atrazine) on the basis of the final fluorometer reading, so that the initial fluorescence would be similar for all 90 tubes. This procedure was repeated five times, resulting in a $67-\mathrm{d}$ chronic exposure to atrazine. The fluorescence method (as a surrogate for growth rate determinations) was validated in a prior 4-week culture experiment in which half the subcultures were exposed to atrazine at $1 \mu \mathrm{g} / \mathrm{L}$. Cell counts were conducted for one clone from the Platte River and one from the culture collection by enumerating cells in a Palmer chamber on days $1,3,5,7,9,11,13$, and 15 after a 2 -week exposure period.

At the conclusion of the chronic treatment, clones were exposed to higher levels of atrazine to investigate the effects of prior atrazine exposure. Six nominal concentrations (93, $187,375,750,1,500$, and $3,000 \mu \mathrm{g} / \mathrm{L}$ ) were used on the basis of prior experiments conducted to determine concentrations eliciting a range of growth responses. Five acute trials were conducted using one replicate of each clone for each trial; in this way, all nine clones (both unexposed and pre-exposed) were tested simultaneously. The five replicated bioassays were conducted, and growth was monitored using a fluorometer on days $1,5,7,9$, and 12 (in the first replicate only, clones were monitored on days $1,3,5,7$, and 9).

Cell counts were also performed for these higher exposures to validate the correlation between cell counts and fluorometric readings. Again, one clone from the Platte River and one clone from culture collection (from both prior exposure histories) were enumerated at $93,187,375$, and $750 \mu \mathrm{g} / \mathrm{L}$ of atrazine on days 7, 9, and 12 using a Sedgewick-Rafter cell.

At the conclusion of the acute-exposure trials, two clones, one from the Platte River (WR) and one from culture collection (L329) from both prior exposure histories, were used to check for viability. Cells of these clones were removed from the six atrazine concentrations and placed in fresh, atrazine-free medium. Because growth in the highest concentrations of atrazine was minimal, cells were allowed to settle on the bottom, and then sterile Pasteur pipettes were used to draw approx. $1 \mathrm{ml}$ to transfer to fresh medium. As a result, this transfer method did not transfer equal numbers of cells from each concentration. Growth was then monitored with a fluorometer for $10 \mathrm{~d}$.

\section{Pesticide analysis}

Gas chromatography-mass spectrometry (GC-MS) analysis was performed on growth medium used in the chronic treatment by the Water Sciences Laboratory, University of Ne- 
braska (Lincoln, NE, USA), to measure actual atrazine concentrations. Analyses of acute exposure concentrations were completed using gas chromatography. On the basis of a split sample that was sent to the Water Sciences Laboratory for quality assurance, GC-MS results yielded $182 \mu \mathrm{g} / \mathrm{L}$ in comparison to $188 \mu \mathrm{g} / \mathrm{L}$ determined by GC. Atrazine levels determined by GC for the acute portion of the study were calculated on the basis of an extraction efficiency of $89.6 \%$.

Chronic treatment concentrations were determined on samples collected prior to algal addition as well as $14 \mathrm{~d}$ after algal addition (by aggregation of culture tubes after transfer into a single sample) to determine atrazine concentrations. Samples were added to $1 \mathrm{~L}$ acid-cleaned, hexane-rinsed amber glass bottles and kept at $4^{\circ} \mathrm{C}$ before solid phase extraction (SPE). Samples were filtered prior to SPE to remove particulates using a precombusted glass fiber filter (Type A/E, 1.0- $\mu \mathrm{m}$ porosity, Gelman Sciences, Ann Arbor, MI, USA). A Hewlett Packard 5890 series II gas chromatograph, interfaced with an HP5970 MSD quadrupole mass spectrometer (Hewlett Packard, Avondale, PA, USA) with a fused silica capillary column (DB-1, $30 \mathrm{~m} \times 0.25-\mathrm{mm}$ i.d., $0.25-\mu \mathrm{m}$ film thickness, J\&W Scientific, Folsom, CA, USA), was used under the following conditions: injector and transfer line temperatures were both $280^{\circ} \mathrm{C}$, the split/splitless purge valve was opened 0.75 min after injection, and the head pressure of the carrier gas ( $\mathrm{He}$, chromatographic grade, Air Products, Lincoln, NE, USA) was $52 \mathrm{kPa}$. The detection limit for atrazine was $0.05 \mu \mathrm{g} / \mathrm{L}$. The GC-MS analyses for the chronic portion of this study showed an initial atrazine concentration of $1.14 \mu \mathrm{g} / \mathrm{L}(n=2)$ in the growth medium and a final concentration after $14 \mathrm{~d}$ with algae present of $1.10 \mu \mathrm{g} / \mathrm{L}(n=2)$. Thus, $C$. cuspidata clones were likely exposed to at least $1 \mu \mathrm{g} / \mathrm{L}$ atrazine over the 67-d exposure period.

Acute levels of atrazine were determined for all six concentrations both before and after algal addition using gas chromatography. Insufficient medium was left for analysis after the concentrations for algal addition were made, so a separate set of concentrations was made for determination of initial atrazine concentrations. Because two sets of medium were made, degradation rates were unknown. All samples were immediately filtered using a glass fiber filter (Type A/E, 1.0- $\mu \mathrm{m}$ porosity, Gelman Sciences) and stored at $4^{\circ} \mathrm{C}$ in $1 \mathrm{~L}$ acidwashed, hexane-rinsed amber glass bottles until extraction. Extraction was completed using Empore 3M extraction disks (with Bakerbond Octadecyl [C 18], J.T. Baker, Philipsburg, NJ, USA). Atrazine concentrations were determined using a Shimadzu model 14-A gas chromatograph (Kyoto, Japan) with a 1-ml/min flow rate, helium carrier gas, nitrogen-phosphorus detector, and a column temperature of $200^{\circ} \mathrm{C}$. Standards were made from $98 \%$ pure atrazine (Chem Service, West Chester, PA, USA), and the limit of detection was $5 \mu \mathrm{g} / \mathrm{L}$. Initial concentrations of atrazine in the acute experiment were 83, 188, $402,860,1,782$, and $3,250 \mu \mathrm{g} / \mathrm{L}$. Final concentrations of atrazine were $57,161,410,840,1,778$, and $3,372 \mu \mathrm{g} / \mathrm{L}$.

\section{Data analysis}

Chronic exposure data were analyzed using a repeated-measures analysis of variance (ANOVA). Repeated-measures analysis was performed on the 2 weeks of measurements between transfers, resulting in five analyses. Multiple analysis of variance (MANOVA) Wilkes' lambda exact $F$-tests were used to examine time and time-by-atrazine effects. Data from day 1
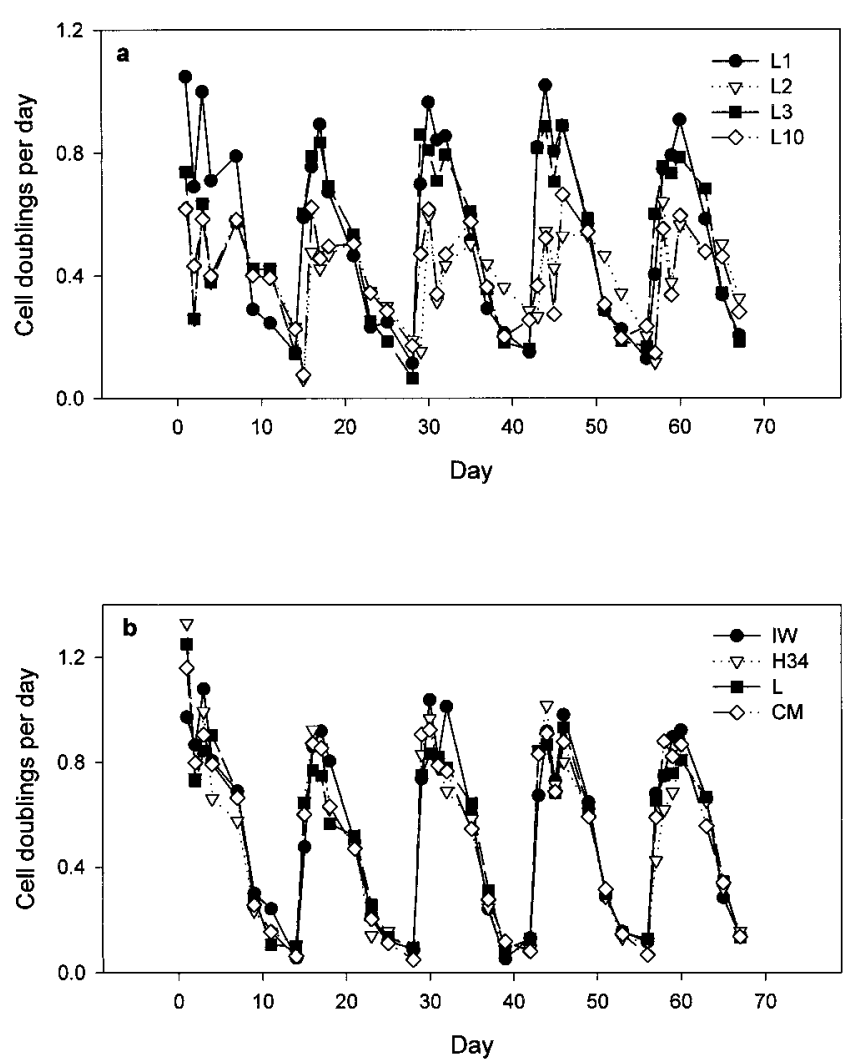

Fig. 1. Growth rates of culture collection (a) and Platte River (b) clones under control treatment (no atrazine). L1, L2, L3, and L10 = Loras College clones; IW (Izak Walton), H34 (Highway 34), L (Locust), and CM (Crane Meadows) = Platte River clones.

only of the chronic study were analyzed using a split-plot ANOVA.

Acute exposure data were analyzed using a split-plot ANOVA. Clone source and prior exposure history interactions were examined to determine whether the effects of exposure were dependent on clone source. Significant atrazine exposure history effects were determined for days 7, 9, and 12 at 0 and $83 \mu \mathrm{g} / \mathrm{L}$ atrazine. Analyses were performed using the SAS/ STAT ${ }^{\circledR}$ User's Guide [31].

\section{RESULTS}

In the absence of atrazine, growth rates of culture collection (Loras) clones were consistent among transfer periods, with maximum growth levels ranging from 0.6 to 0.9 doublings per day (dpd) (Fig. 1a). However, growth rates of Platte River clones of $C$. cuspidata were more similar among clones and more consistent among transfer periods, with a maximum growth rate of approx. $1.0 \mathrm{dpd}$ (Fig. 1b).

\section{Chronic treatment}

A significant atrazine effect on growth rates of $C$. cuspidata clones was seen on the initial day of the chronic treatment ( $p$ $=0.0001)$. Growth rates of all clones under both treatments began to decrease $5 \mathrm{~d}$ after transfer, and similar decreases were observed after all five transfers, indicating possible nutrient depletion or density-dependent effects (Fig. 2). Because of the large decrease in growth rates after day 5 , time effects were significant in all analyses except for days 35 and 42 ( $p=$ 0.0514) (Table 1). Significant atrazine effects were found for 

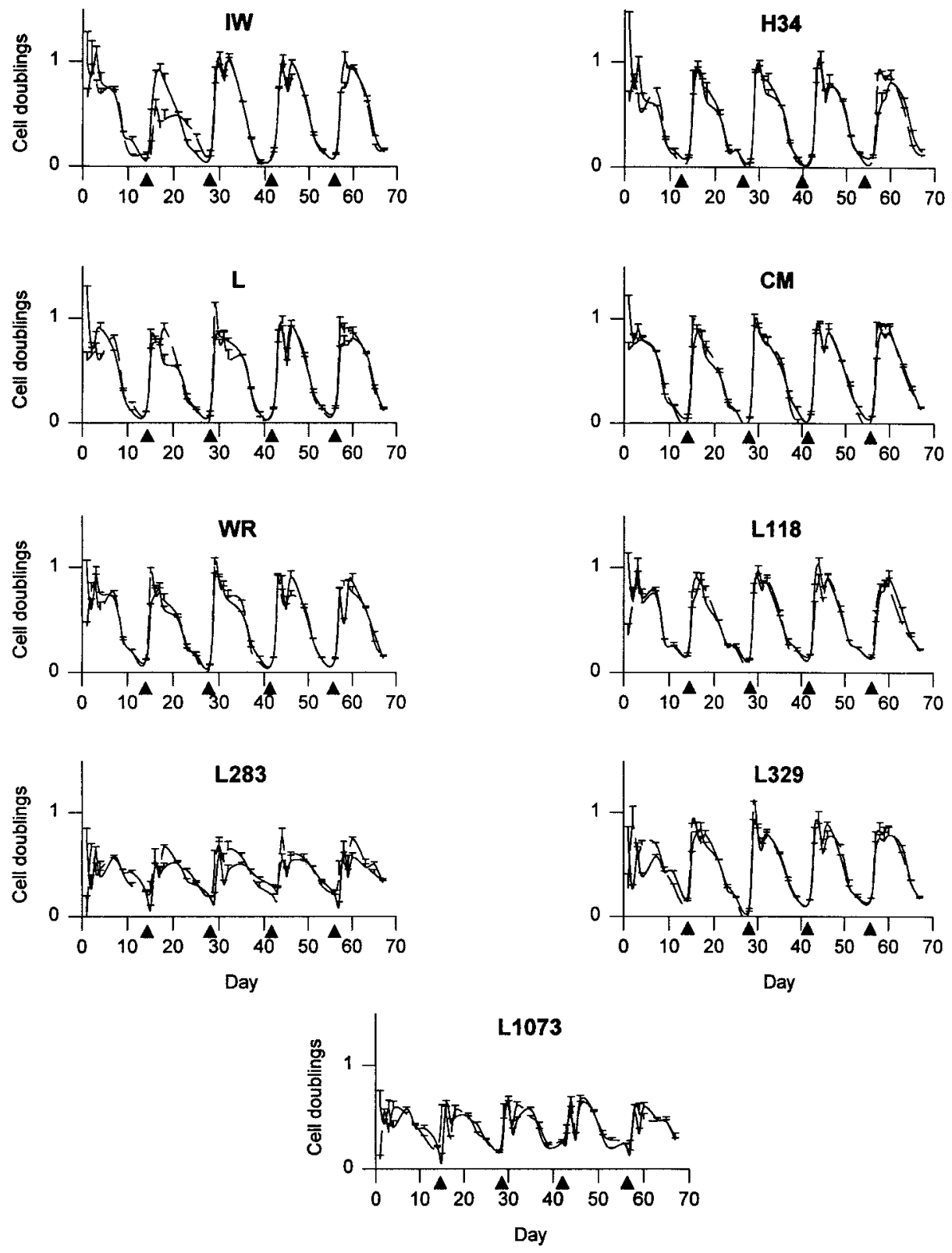

Fig. 2. Growth comparisons of Platte River clones IW (Izak Walton), H34 (Highway 34), L (Locust), CM (Crane Meadows), and WR (Wild Rose) and Loras College (L) diatom clones under chronic atrazine and control treatments. Note that the symbols for each treatment are not visible because the plots are virtually superimposed. Triangles indicate transfer of cultures into fresh medium. Error bars indicate \pm 1 SE $(n=5)$.

three of the five biweekly comparisons during the chronic exposure (Table 1); however, these effects were numerically very small when compared to the overall effect of time on growth rates (Fig. 2). Overall, growth rates showed only slight differences between the two treatments; that is, growth rates were very similar except for the first day (Fig. 2).

Cell densities at both 0 and $1 \mu \mathrm{g} / \mathrm{L}$ atrazine were highly positively correlated with fluorometer readings. The Platte River clone had a Pearson's correlation coefficient of 0.90 and 0.93 under control and atrazine treatments, respectively. The culture collection clone had a correlation coefficient of 0.98 and 0.99 for control and atrazine treatments, respectively, indicating again that fluorometric determination of chlorophyll $a$ provided a good measure of actual growth. Over time, the ratio of relative fluorescence units to cell number did not change, and no difference was noted between ratios of clones exposed to atrazine and those grown under control conditions.

\section{Acute exposure}

Prior exposure history (i.e., treatment during chronic exposure) had a significant effect on growth at the 0 and $83 \mu \mathrm{g} / \mathrm{L}$ atrazine levels (Fig. 3). Higher concentrations were not compared because of low growth in all clones regardless of prior exposure. No significant source- (Platte vs Loras clones) byexposure interactions were detected at any day or exposure level (control or $83 \mu \mathrm{g} / \mathrm{L}$; Table 2). Prior exposure history had a significant effect on all days $(7,9$, and 12) as well in both the 0 and the $83 \mu \mathrm{g} / \mathrm{L}$ atrazine level (Table 2); for example, fluorescence at $0 \mu \mathrm{g} / \mathrm{L}$ was $66 \%$ and at $83 \mu \mathrm{g} / \mathrm{L}$ was $55 \%$ less than the controls on day 7 . Thus, prior chronic exposure to 
Table 1. Summary of repeated-measures analysis of variance (ANOVA) for chronic exposures ( $p$ values). Time and time-byatrazine interaction terms are multiple analysis of variance (MANOVA) Wilkes' lambda exact $F$ tests

\begin{tabular}{lccccc}
\hline & $\begin{array}{c}\text { Days 1 } \\
\text { and 11 }\end{array}$ & $\begin{array}{c}\text { Days 14 } \\
\text { and 25 }\end{array}$ & $\begin{array}{c}\text { Days 28 } \\
\text { and 39 }\end{array}$ & $\begin{array}{c}\text { Days 42 } \\
\text { and 53 }\end{array}$ & $\begin{array}{c}\text { Days 56 } \\
\text { and 67 }\end{array}$ \\
\hline Time & 0.0067 & 0.0227 & 0.0514 & 0.0058 & 0.0019 \\
Time $\times$ Atrazine & 0.0546 & 0.1285 & 0.4634 & 0.0472 & 0.1414 \\
Atrazine & 0.0001 & 0.0001 & 0.0658 & 0.0819 & 0.0022 \\
\hline
\end{tabular}

atrazine resulted in reduced growth rates during subsequent acute exposures as well as under control conditions with no atrazine.

Whereas cell counts performed prior to the chronic and acute experiments revealed no increase in fluorescence per cell (clones were exposed for 2 weeks prior to counting), cell counts at higher concentrations of atrazine (i.e., acute exposure levels) revealed an increase in fluorescence per cell. Platte River clone IW and culture collection clone L329 exhibited a dramatic increase in fluorescence per cell at most concentrations on days 7,9 , and 12 (Table 3).

Cells from all atrazine concentrations were viable when transferred into fresh medium without atrazine at the end of
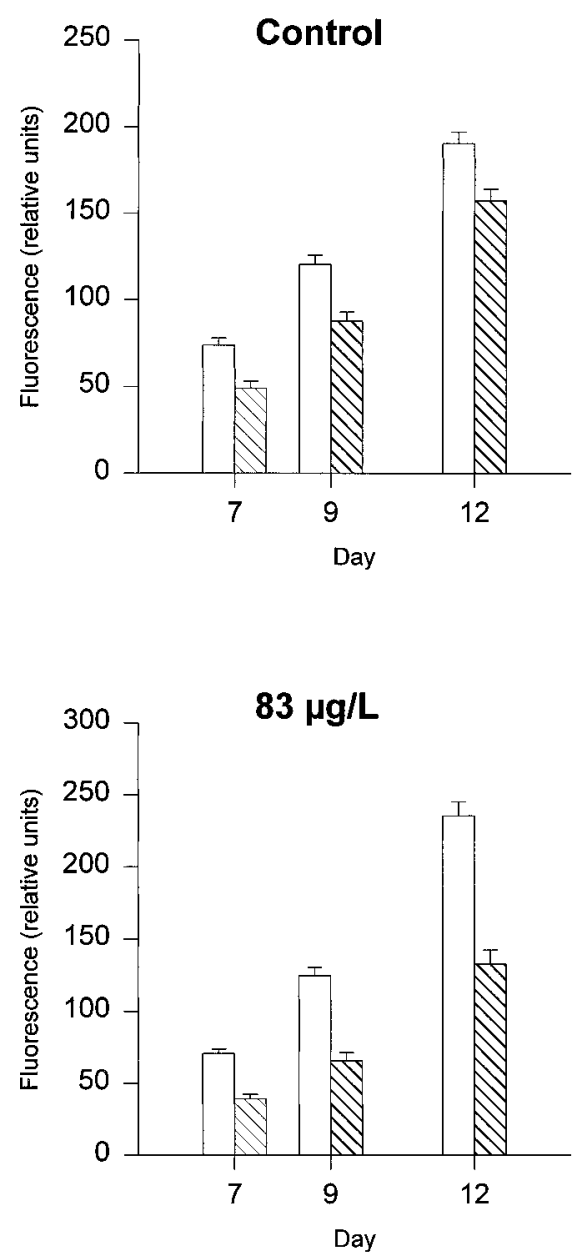

Fig. 3. Growth differences at 0 and $83 \mu \mathrm{g} / \mathrm{L}$ atrazine of pre-exposed (shaded) and control (white) treatments during subsequent atrazine exposure $(n=9)$. Error bars indicate \pm 1 SE (based on least squares means).
Table 2. Summary of significant prior exposure history and historyby-clone effects from days 7,9 , and 12 of the acute exposure $(n=$ 5). FR 0 indicates fluorescence reading at $0 \mu \mathrm{g} / \mathrm{L}$ of atrazine, and FR 83 indicates fluorescence rate at $83 \mu \mathrm{g} / \mathrm{L}$ of atrazine

\begin{tabular}{llll}
\hline ANOVA & Day 7 & Day 9 & Day 12 \\
\hline History FR0 & 0.003 & 0.0029 & 0.0098 \\
History FR83 & 0.0002 & 0.0002 & 0.0001 \\
Source $\times$ History FR0 & 0.4321 & 0.4118 & 0.8529 \\
Source $\times$ History FR83 & 0.3973 & 0.3363 & 0.7968 \\
\hline
\end{tabular}

the acute exposure experiment. Cell densities transferred to new medium differed, depending on the cell density in the source culture. Because transfers were not quantitative, statistical comparisons were not conducted, although it did appear that the Platte River clone (WR) recovered faster at higher atrazine concentrations than the culture collection clone (L329).

\section{DISCUSSION}

\section{Chronic exposure}

Results from the chronic exposure study indicate that continuous exposure to low concentrations of atrazine over a 67-d period did not adversely affect growth rates of the diatom $C$. cuspidata. An initial effect of atrazine was seen on day 1 of the chronic study due to an initial increase in fluorescence at day 0 , when clones were first placed in atrazine-containing medium. This increase in fluorescence diminished by day 1 , resulting in a lower calculated growth rate. Although no differences in growth rate were found over $67 \mathrm{~d}$, it is interesting that significant differences were evident after atrazine exposure ceased, that is, in the $0-\mu \mathrm{g} / \mathrm{L}$ treatment in the subsequent acuteexposure experiment. This effect of prior exposure history may reflect one or more physiological and/or structural changes at the cellular level at low atrazine concentrations, an observation that warrants further investigation.

The results of this study generally are not consistent with previous research showing atrazine effects at $1 \mu \mathrm{g} / \mathrm{L}$, including declines in chlorophyll $a$ and growth. For example, Torres and O'Flaherty [14] found a 41 to $67 \%$ reduction in chlorophyll $a$ in six freshwater algal taxa after a 7-d atrazine treatment, and O'Kelly and Deason [13] reported that growth in 24 of 36 freshwater algal isolates was reduced by 10 to $50 \%$ when exposed to $1 \mu \mathrm{g} / \mathrm{L}$ of atrazine, and two isolates were inhibited

Table 3. Fluorescence per cell $\times 10^{4}$ during acute-exposure treatment of Platte River clone IW and culture collection clone L329 enumerated on days 7, 9, and 12. Control and atrazine columns depict prior exposure history under the chronic treatment

\begin{tabular}{|c|c|c|c|c|c|c|c|}
\hline \multirow[b]{2}{*}{ Clone } & \multirow{2}{*}{$\begin{array}{c}\text { Atrazine } \\
(\mu \mathrm{g} / \mathrm{L})\end{array}$} & \multicolumn{2}{|c|}{ Day 7} & \multicolumn{2}{|c|}{ Day 9} & \multicolumn{2}{|c|}{ Day 12} \\
\hline & & Control & Atrazine & Control & Atrazine & Control & Atrazine \\
\hline \multirow[t]{5}{*}{ IW } & 0 & 29.76 & 26.69 & 28.78 & 32.84 & 30.57 & 35.07 \\
\hline & 93 & 57.44 & 53.01 & 37.04 & 52.22 & 41.51 & 49.73 \\
\hline & 187 & 54.62 & 56.90 & 44.30 & 62.30 & 44.47 & 57.55 \\
\hline & 375 & 42.40 & 55.12 & 39.72 & 62.01 & 50.27 & 70.76 \\
\hline & 750 & 39.38 & 50.23 & 34.73 & 56.85 & 30.74 & 66.73 \\
\hline \multirow[t]{5}{*}{ L329 } & 0 & 19.59 & 18.79 & 18.63 & 17.96 & 19.13 & 18.87 \\
\hline & 93 & 30.92 & 30.02 & 33.72 & 32.57 & 36.30 & 38.29 \\
\hline & 187 & 36.07 & 36.79 & 41.89 & 38.81 & 38.17 & 39.71 \\
\hline & 375 & 36.08 & 32.83 & 37.99 & 31.78 & 45.17 & 43.50 \\
\hline & 750 & 18.50 & 8.13 & 27.15 & 16.82 & 27.33 & 21.91 \\
\hline
\end{tabular}


by $>50 \%$ after a 14-d exposure. The effects of atrazine recorded initially in this study parallel the findings of DeNoyelles et al. [17], in which increases in in vivo fluorescence were seen at $1 \mu \mathrm{g} / \mathrm{L}$ after a 2 -min exposure. The results of this study revealed an initial atrazine effect that decreased over time; by day 3 of the exposure to $1 \mu \mathrm{g} / \mathrm{L}$, no appreciable differences were noted between treatments.

The absence of chronic effects for the duration of the 67-d exposure is in agreement with the findings of van den Brink et al. [18], in which no species composition or abundance changes were detected in an algal community exposed to 5 $\mu \mathrm{g} / \mathrm{L}$ of atrazine for 6 weeks. However, they did note a slight shift in several functional parameters, such as dissolved oxygen, $\mathrm{pH}$, and alkalinity, indicating a slight decrease in photosynthetic activity. Brockway et al. [25] did not detect a significant change in oxygen production in microcosms treated with $5 \mu \mathrm{g} / \mathrm{L}$ of atrazine during a $75-\mathrm{d}$ exposure. Chronic exposure to $10 \mu \mathrm{g} / \mathrm{L}$ of atrazine for 3 weeks was sufficient to reduce apparent gross primary productivity in artificial streams [23]. However, chronic exposures are generally lower in lotic systems, especially in higher-order streams, where peak concentrations of contaminants are diluted by increased flows but are present for longer durations. Research utilizing environmentally realistic exposures appears to show that these lower concentrations do not impair periphyton growth but can affect higher trophic levels; Gruessner and Watzin [32] found earlier emergence of benthic invertebrates in laboratory microcosms exposed to realistic atrazine concentrations.

Some researchers have documented increases in chlorophyll $a$, species richness, and biomass under low concentrations of atrazine. Torres and O'Flaherty [14] found that atrazine concentrations of 0.1 and $0.5 \mu \mathrm{g} / \mathrm{L}$ stimulated chlorophyll production by up to $156 \%$. Pratt et al. [33] noted stimulatory effects in species richness and biomass at low atrazine concentrations and a $57 \%$ increase in chlorophyll $a$. No increase in growth was seen during the 67-d chronic exposure in the present study. Increased growth of algae under low atrazine concentrations has been hypothesized to be the result of nitrogen utilization from atrazine metabolites [14]. However, atrazine concentrations showed little degradation of parent compound in this study; furthermore, the additional nitrogen in a $1-\mu \mathrm{g} / \mathrm{L}$ concentration of atrazine would be too small to make a difference in nutrient availability.

\section{Acute exposures}

The results from the present study indicate that chronic, low-level exposure to atrazine inhibits growth during subsequent exposure to higher atrazine concentrations; prior exposure resulted in decreased growth in both 0 and $83 \mu \mathrm{g} / \mathrm{L}$ atrazine treatments. Decreased growth at higher concentrations $(188,402,860,1,782$, and 3,250 $\mu \mathrm{g} / \mathrm{L})$ was not discernable because of direct growth inhibition by atrazine. Evidence for induced resistance or increased tolerance in algae resulting from prior exposure to atrazine is lacking. Thus, unlike the results obtained from heavy-metal exposures [21,24], algal communities preexposed to low levels of atrazine do not appear to have increased tolerance to subsequent exposures [24,25]. Community-level studies using a single atrazine exposure have revealed more tolerant species by examining algal community-level changes $[17,23]$. However, increased tolerance from prior exposure was not reported. Atrazine tolerance was investigated by Kosinski and Merkle [23], but none was detected in communities pre-exposed to $10 \mu \mathrm{g} / \mathrm{L}$. In addition, they assessed the influence of the source of the algae on their response to the herbicide; effects of higher concentrations of atrazine ( 1 and $10 \mathrm{mg} / \mathrm{L})$ were similar in both algal communities from both pasture and row crop-fed streams. Algae from the pasture spring were inhibited less, but the effects were longer lasting (photosynthesis was reduced for a full 3 weeks). In comparison, algal communities obtained from an agriculturally impacted stream recovered from the $1 \mathrm{mg} / \mathrm{L}$ of atrazine in 1 week. These differences could have been related to prior exposure histories (i.e., original collection sites) but more likely resulted from differences in species composition. Gustavson and Wängberg [24] also attempted to induce tolerance in algal communities using copper and atrazine. Although they were able to document increased tolerance of communities pre-exposed to copper, they were unable to find any changes in atrazine tolerance. Increased tolerance also was not detected by Brockway et al. [25] when a subsequent dose of $59 \mu \mathrm{g} / \mathrm{L}$ of atrazine was applied to microcosms previously exposed to 0.5 $\mu \mathrm{g} / \mathrm{L}$ for $29 \mathrm{~d}$. However, periphyton communities are inherently complex, so they may mask prior exposure effects evident when examined at the species level.

Photosystem II (PS II) inhibitors block electron transport, which can be monitored using a fluorometer. In PS II, atrazine binds to the D1 protein, blocking the transfer of electrons so that absorbed light energy is not transferred to electrochemical energy [34] but re-emits the photon of light as florescence [35]. Thus, increased fluorescence can be used as a sensitive indicator of impairment in the electron transport chain. Cell counts and fluorometer readings prior to the chronic exposure revealed no increase in fluorescence per cell. At low concentrations, PS II inhibitors have not been shown to increase fluorescence. For example, Arsalane et al. [36] did not detect appreciable increases in fluorescence of the diatom Phaeodactylum tricornutum until atrazine or simazine concentrations exceeded $100 \mu \mathrm{g} / \mathrm{L}$. Increases in fluorescence were seen at lower concentrations of terbutryne (a PS II-inhibiting herbicide), with large increases in fluorescence in the green alga Scenedesmus dimorphus at $50 \mu \mathrm{g} / \mathrm{L}$ and in the diatom Nitzschia acicularis at 2 to $3 \mu \mathrm{g} / \mathrm{L}$ [37]. The $1-\mu \mathrm{g} / \mathrm{L}$ concentration of atrazine used in the present chronic exposure was apparently insufficient to create detectable increases in fluorescence in $C$. cuspidata, except on the initial day of exposure.

When $C$. cuspidata was exposed to higher levels of atrazine, increases in fluorescence per cell occurred. Furthermore, the increase was elevated as the concentration increased from 83 to $402 \mu \mathrm{g} / \mathrm{L}$. Once concentrations of PS II inhibitors are high enough to block electron transport (resulting in increased fluorescence), fluorescence increases until a saturation point is reached, beyond which further increases are not evident [36,38]. Because of the fluorescence increase caused by PS II inhibitors, EC50 values calculated on the basis of a fluorescence-generated dose-response curve are not reliable. This was manifested in several clones wherein the $83-\mu \mathrm{g} / \mathrm{L}$ fluorescence exceeded the control but did not correlate with cell counts.

\section{Resistance mechanisms}

Herbicide resistance in weeds was first documented in 1968, and the number of weed biotypes conferring resistance to PS II inhibitors has since increased to 57 species [39]. Evolution of resistance to PS II inhibitors in plants nearly always involves a single mutation in the $p s b A$ gene that codes for the D1 protein. The resulting change in the D1 protein reduces the 
binding affinity of PS II inhibitors but does not change the binding affinity of the $\mathrm{Q}_{\mathrm{B}}$ plastiquinone [34]. In contrast, crop tolerance to herbicides is generally due to metabolism [39]. In algae, the only documented resistance to PS II-inhibiting herbicides has been after induced mutagenesis [40]. Further research should address the lack of tolerance and resistance to atrazine in freshwater algae before assuming that current loading rates of atrazine to aquatic systems are insufficient to pose a significant risk to ecosystem integrity, especially in light of recent evidence of additive herbicide effects in benthic algal communities [41].

In conclusion, chronic exposure of $C$. cuspidata to low concentrations of atrazine increased the sensitivity of this diatom to higher pulses of the herbicide. Thus, chronic exposure to atrazine concentrations typical of base flow in the Platte River did not increase its tolerance to higher atrazine levels. This lack of increased tolerance in a common benthic diatom after a realistic chronic exposure indicates that the levels of atrazine presently found in many lotic ecosystems does not enhance but actually inhibits the growth of periphyton during higher pulses of atrazine. Given the important environmental implications of these findings, further studies on additional algal species and entire algal communities are clearly warranted.

Acknowledgement-This study was funded by a grant from the U.S. EPA Region VII through the Regionally Applied Research Effort program in cooperation with Anthony Carlson, EPA Environmental Research Laboratory, Duluth, and additional support from the UNL Water Center/Environmental Programs. Statistical guidance was provided by Steve Kachman, and John Holz assisted with figure preparations. Appreciation is extended to David Czarnecki for providing culture collection clones and to two anonymous reviewers for very helpful suggestions on the manuscript. This is Journal Series 12165 of the Agricultural Research Division at the University of Nebraska.

\section{REFERENCES}

1. Novotny V, Olem H. 1994. Water Quality: Prevention, Identification, and Management of Diffuse Pollution. Van Nostrand Reinhold, New York, NY, USA.

2. Thurman EM, Goolsby DA, Meyer MT, Kolpin DW. 1991. Herbicides in surface waters of the midwestern United States: The effect of spring flush. Environ Sci Technol 25:1794-1796.

3. Moreland DE. 1980. Mechanisms of action of herbicides. Ann Rev Plant Physiol 31:597-638.

4. Eisler R. 1989. Atrazine hazards to fish, wildlife, and invertebrates: A synoptic review. US Fish Wildl Serv Biol Rep 85:118.

5. Goolsby DA, Battaglin WA, Thurman EM. 1993. Occurrence and transport of agricultural chemicals in the Mississippi River Basin July through August 1993. USGS Circular 1120-C. U.S. Geological Research Center, Columbia, MO.

6. Jones TW, Kemp WM, Stevenson JC, Means JC. 1982. Degradation of atrazine in estuarine water/sediment systems and soils. J Environ Qual 11:632-638.

7. Mirgain I, Green GA, Monteil H. 1993. Degradation of atrazine in laboratory microcosms: Isolation and identification of the biodegrading bacteria. Environ Toxicol Chem 12:1627-1634.

8. Green RE, Obien SR. 1969. Herbicide equilibrium in soil in relation to soil water content. Weed Sci 17:514-519.

9. Langan MM, Hoagland KD, Everson AR. 1995. Pesticide levels in storm runoff from agricultural stream sites with different riparian buffer strips. Proceedings, Platte River Basin Ecosystem Symposium, Kearney, NE, USA, February 28-March 1, pp 223233.

10. Dewey SL. 1986. Effects of the herbicide atrazine on aquatic insect community structure and emergence. Ecology 67:148-162.

11. Hughes JS, Alexander MM, Balu K. 1988. An evaluation of appropriate expressions of toxicity in aquatic plant bioassays as demonstrated by the effects of atrazine on algae and duckweed. In Adams WJ, Chapman GA, Landis WG, eds, Aquatic Toxi- cology and Hazard Assessment, Vol 10. Special Technical Publication. American Society for Testing and Materials, Philadelphia, PA, pp 531-547.

12. Millie DF, Hersh CM. 1987. Statistical characterizations of the atrazine-induced photosynthetic inhibition of Cyclotella meneghiniana (Bacillariophyta). Aquat Toxicol 10:239-249.

13. O'Kelley JC, Deason TR. 1976. Degradation of pesticides by algae. EPA-600/3-76-022. U.S. Environmental Protection Agency, Athens, GA.

14. Torres AMR, O'Flaherty LM. 1976. Influence of pesticides on Chlorella, Chlorococcum, Stigeoclonium (Chlorophyceae), Tribonema, Vaucheria (Xanthophyceae) and Oscillatoria (Cyanophyceae). Phycologia 15:25-36.

15. Solomon KR, et al. 1996. Ecological risk assessment of atrazine in North American surface waters. Environ Toxicol Chem 15:3176.

16. Jurgensen TA, Hoagland KD. 1990. Effects of short-term pulses of atrazine on attached algal communities in a small stream. Arch Environ Contam Toxicol 19:617-623.

17. DeNoyelles F, Kettle WD, Sinn DE. 1982. The responses of planktonic communities in experimental ponds to atrazine, the most heavily used pesticide in the United States. Ecology 63:12851293.

18. van den Brink PJ, van Donk E, Gylstra R, Crum SJH, Brock TCM. 1995. Effects of chronic low concentrations of the pesticides chlorpyrifos and atrazine in indoor freshwater microcosms. Chemosphere 31:3181-3200.

19. Cairns J Jr. 1983. Are single species toxicity tests alone adequate for estimating environmental hazard? Hydrobiologia 100:47-57.

20. Joern A, Hoagland KD. 1996. In defense of whole-community bioassays for risk assessment. Environ Toxicol Chem 15:407409.

21. Blanck H, Wängberg S-C. 1988. Induced community tolerance in marine periphyton established under arsenate stress. Can J Fish Aquat Sci 45:1816-1819.

22. Niederlehner BR, Cairns J Jr. 1993. Effects of previous zinc exposure on $\mathrm{pH}$ tolerance of periphyton communities. Environ Toxicol Chem 12:743-753.

23. Kosinski RJ, Merkel MG. 1984. The effect of four terrestrial herbicides on the productivity of artificial stream algal communities. J Environ Qual 13:75-82.

24. Gustavson K, Wängberg S-C. 1995. Tolerance induction and succession in microalgae communities exposed to copper and atrazine. Aquat Toxicol 32:283-302.

25. Brockway DL, Smith PD, Stancil FE. 1984. Fate and effects of atrazine in small aquatic microcosms. Bull Environ Contam Toxicol 32:345-353.

26. Polne-Fuller M. 1991. A novel technique for preparation of axenic cultures of Symbiodinium (Pyrrophyta) through selective digestion by amoebae. J Phycol 27:552-554.

27. Guillard RRL. 1975. Culture of phytoplankton for feeding marine invertebrates. In Smith WL, Chanley MH, eds, Culture of Marine Invertebrate Animals. Plenum, New York, NY, USA, pp 29-60.

28. Atlas RM. 1993. Handbook of Microbiological Media. CRC, Ann Arbor, MI, USA.

29. Brand LE, Guillard RRL, Murphy LS. 1981. A method for rapid and precise determination of acclimated phytoplankton reproduction rates. J Plank Res 3:193-201.

30. Guillard RRL. 1973. Division rates. In Stein JR, ed, Handbook of Phycological Methods: Culture Methods and Growth Measurements. Cambridge University Press, London, UK, pp 289311.

31. SAS Institute, Inc. 1989. SAS/STAT ${ }^{\circledR}$ User's Guide, Ver 6.0. Cary, NC, USA.

32. Gruessner B, Watzin MC. 1996. Response of aquatic communities from a Vermont stream to environmentally realistic atrazine exposure in laboratory microcosms. Environ Toxicol Chem 15:410419.

33. Pratt JR, Bowers NJ, Niederlehner BR, Cairns J Jr. 1988. Effects of atrazine on freshwater microbial communities. Arch Environ Contam Toxicol 17:449-457.

34. Fuerst PE, Norman MA. 1991. Interactions of herbicides with photosynthetic electron transport. Weed Sci 39:458-464.

35. Krugh BW, Miles D. 1996. Monitoring the effects of five "nonherbicidal" pesticide chemicals on terrestrial plants using chlorophyll fluorescence. Environ Toxicol Chem 15:495-500.

36. Arsalane W, Parésys G, Duval J-C, Wilhelm C, Conrad R, Büchel 
C. 1993. A new fluorometric device to measure the in vivo chlorophyll $a$ fluorescence yield in microalgae and its use as a herbicide monitor. Eur J Phycol 28:247-252.

37. Goldsborough LG, Robinson GGC. 1984. A simple bioassay for photosystem-II inhibitors in water using in vivo chlorophyll fluorescence. Weed Res 24:351-358.

38. Zweig G, Tamas I, Greenburg E. 1963. The effect of photosynthesis inhibitors on oxygen evolution and fluorescence of illuminated Chlorella. Biochim Biophys Acta 66:196-205.
39. Gronwald JW. 1994. Resistance to photosystem II inhibiting herbicides. In Powles S, Holtum J, eds, Herbicide Resistance in Plants: Biology and Biochemistry. CRC, Chelsea, MI, USA.

40. Sivan A, Arad SM. 1995. A mutant of the red microalga Porphyridium sp. (Rhodophyceae) resistant to DCMU and atrazine. Phycologia 34:299-305.

41. Carder JC, Hoagland KD. 1998. Combined effects of alachlor and atrazine on benthic algal communities in artificial streams. Environ Toxicol Chem 17:1415-1420. 